\title{
ITINERARIUM MENTIS IN DEUM PER NIHILUM \\ O NIILISMO COMO DESAFIO AO CRISTIANISMO
}

\section{Itinerarium mentis in Deus per nihilum Nihilism as a challenge to Christianity}

\author{
Paulo Sérgio Carrara CSSR *
}

Resumo: O artigo busca refletir as chances do cristianismo no contexto pós-moderno, cuja característica principal se define como niilismo, traço fundamental das filosofias de Nietzsche e Heidegger. A hipótese apresentada parte do pressuposto de que o abandono da metafísica clássica não representa somente uma ameaça à fé cristã, mas lhe desafia a uma nova configuração. O filósofo Gianni Vattimo aproxima cristianismo e niilismo, apontando para os cristãos um caminho possível, mesmo se os cristãos não acolhem todos os pressupostos de sua filosofia. A fé cristã encontra na sua vertente mística os elementos de que necessita para enfrentar os desafios do niilismo, pois sua dimensão prático-existencial tem mais chances de falar ao homem de hoje do que seu discurso metafísico. Por outro lado, muitos místicos enfrentaram o nada na sua busca de Deus, mostrando que o niilismo não é estranho à experiência de fé.

Palavras-chave: Metafísica, Cristianismo, Niilismo, Gianni Vattimo, Mística.

Abstract: The article seeks to reflect on the possibilities of Christianity in the postmodern context, the principal characteristic of which is defined as nihilism, a fundamental trait of the philosophies of Nietzsche and Heidegger. The hypothesis presented starts from the presupposition that the abandonment of classical metaphysics not only presents a threat to Christian faith but also challenges it to form a new configuration. The philosopher Gianni Vattimo compares Christianity to Nihilism, showing to Christians a possible path, even when Christians do not accept all the presuppositions of his philosophy. Christian faith finds in its mystical

* Faculdade Jesuíta de Filosofia e Teologia, Instituto Santo Tomás de Aquino (Belo Horizonte). Artigo recebido em 15.10.2011 e aprovado em 25-10-2011. 
dimension the elements which it needs to face the challenges of nihilism, because its practical and existential aspect has more possibilities of speaking to the contemporary person than its metaphysical discourse. Many mystics face the "nothing" in their search for God, showing that nihilism is not foreign to the experience of God.

Keywords: Metaphysics, Christianity, Nihilism, Gianni Vattimo, Mystical.

\section{Introdução}

$\mathrm{H}$ enrique de Lima Vaz, no seu opúsculo sobre filosofia e mística, afirma que não há mística sem transcendência, porque a mística postula um inusitado encontro da pessoa com a transcendência. Neste caso, o homem pós-moderno só voltaria a vislumbrar a autêntica experiência mística depois de haver atravessado o deserto do niilismo ${ }^{1}$. Esse deserto, no entanto, parece estender-se cada vez mais, uma vez que o niilismo caracteriza a pós-modernidade. Segundo o filósofo Franco Volpi, "quem atravessa a linha alcança apenas a zona em que o niilismo passa a ser a condição normal, no sentido de que se torna um aspecto essencial e constitutivo da realidade. Por isso, não se deixa facilmente conter e muito menos extirpar"2 $^{\prime 2}$ O homem pós-moderno encontra no niilismo o seu novo habitat. Ele nega a transcendência e crê apenas na imanência, fechando-se a um possível encontro com a divindade, o que inviabiliza a experiência mística. Sem negar a afirmação de Henrique de Lima Vaz, correta tanto do ponto de vista filosófico como teológico, constata-se, por outro lado, que o niilismo se configura como "um deserto que cresce"3. Mas, paradoxalmente, desponta nesse deserto novo interesse pela mística. Por que razão? O niilismo realmente se opõe à experiência mística?

O cristianismo necessita irradiar sua mensagem no contexto em que está inserido. Foi assim ao longo da histórica. Seu encontro com a cultura grega obrigou os pensadores cristãos a interpretar o evangelho com categorias filosóficas novas. Num grande esforço hermenêutico, os cristãos concluíram que a verdade buscada pela filosofia se expressava plenamente na revelação de Jesus Cristo. O homem grego não precisou negar sua filosofia para aceitar Cristo. Ela possuía elementos de verdade, sementes do Verbo, que permitiram a acolhida da verdade de Jesus. Cada época exigiu grande esforço epistemológico dos cristãos para reinterpretarem a verdade cristã, tornando-a plausível ao longo da história. Atualmente, para que permaneça plausível, a mensagem cristã se confronta com o niilismo que, talvez,

${ }^{1}$ Cf. H. L. VAZ, Experiência mística e filosofia na tradição ocidental, São Paulo: Loyola, 2009, p. 99.

${ }^{2}$ F. VOLPI, $O$ niilismo, São Paulo: Loyola, 1999, p. 89.

${ }^{3}$ Cf. ibid., p. 89. 
contenha suas próprias sementes do Verbo. Nesse artigo, quer-se avaliar as chances da vertente mística do cristianismo num contexto niilista. Parte-se da hipótese de que a rica experiência mística testemunhada pela tradição cristã não se mostra totalmente estranha ao niilismo. Uma vez que o niilismo se tornou o contexto no qual a mensagem cristã deve ainda ressoar, porque não vê-lo como o novo deserto onde, quem sabe, o homem vislumbrará o rosto de Deus? São Boaventura cunhou a expressão itinerarium mentis in Deum. Ele teologizou os caminhos para o conhecimento de Deus ${ }^{4}$. Como pensar esse itinerário a partir do confronto com o niilismo? Seria possível um itinerarium mentis in Deum per nihilum?

\section{O niilismo}

O niilismo evoca sempre os mestres da suspeita, Nietzsche, Freud e Marx, para os quais a religião anestesia as feridas da alma causadas pelas realidades filosófica, psíquica e social. Aqui interessa o aspecto mais filosófico do niilismo, sem que se queira aprofundá-lo exaustivamente. Em resumo, o niilismo consiste numa reação à filosofia moderna e seus pressupostos, sobretudo seu essencialismo e seus argumentos transcendentais ${ }^{5}$. São considerados pais da pós-modernidade niilista especialmente Nietzsche e Heidegger. Nietzsche ${ }^{6}$ nega que se possa conhecer a verdadeira estrutura do real, como pretendia a metafísica clássica em sua visão objetivista. $\mathrm{O}$ filósofo se recusa a pensar o ser como fundamento, porque não há uma ordem objetiva do mundo que o pensamento consiga dominar totalmente. Ele define o niilismo como falta de finalidade. Não há resposta para a pergunta: para quê? "Que significa o niilismo? Que os valores supremos se depreciaram"7. O desaparecimento dos valores tradicionais causa a sensação de ausência de sentido, porque se a vida carece de um fundamento último, o homem se sente à deriva, sem rumo certo. A história não tem um fim último, falta-lhe um princípio organizador que lhe dê unidade. O próprio conceito de verdade, tão significativo para o cristianismo, pulverizase no tempo da interpretação hermenêutica. A negação da metafísica provoca descrença num mundo verdadeiro ${ }^{8}$. Cada subjetividade constrói a sua

\footnotetext{
4 J. MANNES, “A possibilidade do conhecimento de Deus em São Boaventura”, $R E B$ n. 281 (2011) pp. 69-86.

${ }^{5}$ Uma boa síntese sobre o niilismo e a pós-modernidade se encontra no Dicionário de Filosofia de Cambridge. Cf. B. MAGNUS, "Postmodern", in: R. ANDI (Org.), The Cambridge dictionary of filosofhy, Cambridge: Cambridge Press, 2001, pp. 725-726.

${ }^{6}$ Segundo Franco Volpi, "não é exagero considerar Nietzsche o profeta máximo e o teórico maior do niilismo, alguém que cedo intui a doença do século". Cf. VOLPI, O niilismo, p. 43.

${ }^{7}$ F. NIETZSCHE, Vontade de potência, São Paulo: Vozes, p. 139.

${ }^{8}$ Cf. ibid., p. 144.
} 
verdade sem referência a uma possível verdade última. A interpretação substitui a idéia de verdade, uma vez que o pensamento humano não consegue mais se organizar a partir de um fundamento que lhe dê consistência.

A antropologia nietzschiana resume-se numa visão de homem sem referência religiosa e sem apelo ao transcendente. $\mathrm{O}$ único sentido possível para a realidade encontra-se no imanente. A fidelidade ao mundo supõe uma ruptura radical com os valores religiosos, porque separam o homem do verdadeiro mundo, fazendo-o viver na ilusão de uma verdade transcendente e estável. O filósofo proclama a morte de Deus, uma vez que o real carece de fundamento. O anúncio da morte de Deus foi tanto um evento cultural, enquanto ruptura da interpretação da vida e do mundo pela moral cristã, quanto um desenvolvimento filosófico, abandono de Deus como hipótese explicativa dos fenômenos do mundo. Para enfatizar o caráter provisório de todo conhecimento, o filósofo rejeita a idéia da possibilidade de um saber absoluto e transcendente. A morte de Deus não é só o abandono da idéia de Deus, mas de todo tipo de metafísica que poderia substituí-lo?.

Heidegger, por sua vez, postula uma antropologia de desapropriação do ser. Seu trabalho focaliza a tradicional questão metafísica. Segundo Vattimo, "o que Heidegger chama de metafísica é, na verdade, a crença em uma ordem objetiva do mundo que o pensamento deveria reconhecer para poder adequar tanto suas descrições da realidade quanto suas escolhas morais"10. O filósofo alemão quer encontrar uma resposta para a questão do ser. Critica filosofias anteriores que quiseram pensar o ser como uma propriedade ou essência presente nas coisas, como se o ser se identificasse com o fundamento e a objetividade. O ser, segundo ele, é desprovido de objetividade e o erro da metafísica clássica está na consideração do ser como substância. O ser só pode ser pensado a partir do sujeito que o conhece na sua concreta existência no mundo (dasein). As estruturas humanas criam o acesso ao ser, cujo conhecimento se revela condicionado pela situação histórica do sujeito. A razão, nesse caso, não apreende totalmente a verdade e a linguagem determina o homem e não vice-versa. A linguagem emerge como a casa do ser. Único meio através do qual o ser torna-se acessível e inteligível. A linguagem fala ao homem e expressa a modalidade do ser ${ }^{11}$. O dasein articula-se em uma tríplice estrutura: compreensão, interpretação e discurso. A estrutura central do ser humano no mundo se dá num círculo

\footnotetext{
${ }^{9}$ Cf. R. SHACHT, "Nietzsche”, in: R. AUDI (Org.). The Cambridge dictionary of philosophy, p. 613-616, aqui p. 615 .

${ }^{10}$ G. VATTIMO, Depois da cristandade: Por um cristianismo não religioso, Rio de Janeiro/ São Paulo: Record, 2004, p. 22.

${ }^{11}$ Cf. C. B. GUIGNON, "Martin Heidegger", in: R. AUDI (Org.). The Cambridge dictionary of philosophy, pp. 370-373, aqui p. 371 .
} 
de compreensão e interpretação. Na realidade, o ser-no-mundo não significa estar em contato com tudo que constitui o mundo, mas estar familiarizado com um uma totalidade de significações. Tal familiaridade se define como compreensão. Todo ato de conhecimento surge como articulação e interpretação de tal familiaridade ${ }^{12}$. Não há, para Heidegger, objetividade universal como fundamento de uma racionalidade partilhada e aceita de forma unânime ${ }^{13}$. Ao criticar o pensamento metafísico, o filósofo não se opõe à existência de Deus, mas à do Deus metafísico, ou seja, recusa a conceber Deus como ser absoluto, eterno, imaterial e criador da ordem do mundo. Essa concepção, enraizada no pensamento grego, acaba por domesticar Deus, porque o compreende, segundo a lógica da racionalidade humana, como organizador do mundo ${ }^{14}$. De acordo com Grondin, "Heidegger procura um Deus fora da metafísica, um Deus que não está aí para nos tranqüilizar, mas para enlouquecer nossas certezas"15.

Não há duvida de que o niilismo expressa o mal-estar da civilização e revela uma imagem do mundo fragmentada, carente de sua unidade clássica. Segundo Gianni Vattimo, os meios de comunicação aprofundam o niilismo, porque esfacelam a realidade, apresentando-a destituída de um princípio unificador. Nos meios de comunicação, a realidade emerge diversificada, com vários matizes. É como se a profecia de Nietzsche se cumprisse: o verdadeiro mundo se transformou em fábula. A realidade, em si mesma, é ilusão de ótica, porque atravessada por múltiplas imagens, interpretações e reconstruções desconectas, sem uma lógica central. Nesse contexto, o ideal de emancipação sustentado pela razão iluminada da modernidade desaparece. Eis que surge novo ideal de emancipação, mais individual e menos coletivo, mais subjetivo e menos histórico, alicerçado na oscilação e no pluralismo. Corrói-se o próprio princípio de realidade ${ }^{16}$.

O niilismo se caracteriza como dissolução de todo fundamento. Numa paráfrase de São Boaventura, foi designado como "itinerarium mentis in nihilum ${ }^{17 " .}$. Com a proclamação da morte de Deus tornou-se impossível pensar em valores e fundamentos que dêem sentido à vida. Nega-se a finalidade do homem e do cosmo. A realidade configura-se como um compor-se de horizontes sem significado. A existência se mostra privada de um sentido último e a energia vital a nada tende. Desconfia-se dos ideais de progresso, uma vez que o devir característico da história humana não

${ }^{12}$ Cf. G. VATTIMO, El fin de la modernidad: Nihilismo e hermenéutica en la cultura posmoderna, Barcelona: Gedisa, 2000, p. 103-104.

${ }^{13}$ Cf. VATTIMO, La società trasparente, Roma: Garzanti, 2000, p. 19-20.

${ }^{14}$ Cf. J. GRONDIN, J. "O retorno espetacular de Deus na filosofia. Manifestações e razões de um fenômeno", Concilium (Br) n. 337 (2010) p. 91-99, aqui p. 95-96.

${ }^{15}$ Ibid., p. 96.

${ }^{16}$ Cf. VATTIMO, La società trasparente, p. 15.

${ }^{17}$ VOLPI, $O$ niilismo, p. 7. 
tem porto de chegada. O sujeito se reduz a mera função, perdendo sua dignidade de pessoa. Os juízos de valores se equivalem, o que anula a validade dos juízos de valor ${ }^{18}$. São lapidares as palavras de Franco Volpi:

O niilismo deu-nos a consciência de que nós, modernos, não temos raízes, navegamos sem destino por entre os arquipélagos da vida, do mundo, da história, porque, no desencanto, não existe mais bússola para orientar; não há mais rotas, percursos conhecidos de que lançar mão, nem metas preestabelecidas a ser alcançadas ${ }^{19}$.

Tanto o niilismo de Nietzsche quanto o de Heidegger mostram que o ser não coincide com aquilo que é estável, fixo e permanente, mas com o evento, o diálogo, a oscilação e a interpretação. Como se a vida transgredisse todos os a priori dogmáticos com os quais se quis interpretá-la. Como se ultrapassasse as leis rígidas que a amarram. Não se encontra mais onde sempre se acreditou que estivesse. "Ela é lábil, furtiva, lúdica e, também, um pouco maliciosa" 20 .

\section{O desafio do niilismo}

O niilismo tornou-se um ar que se respira, "vivemos em meio dele"21. Do ponto de vista coletivo, a conseqüência mais óbvia do niilismo se encontra no relativismo ético e moral. Num contexto em que se nega um fundamento transcendente para o mundo e a histórica, acentua-se a crença na ciência e na técnica, que passam a organizar a vida no planeta. E quando a ciência e a técnica assumem o lugar dos valores, "os imperativos morais lembram freios de bicicleta, usados em avião a jato"22. Os valores permanecem no âmbito das crenças pessoais, sem incidência no coletivo. Nesse caso, "a ética e a moral têm a beleza de fósseis $\operatorname{raros}^{\prime 23}$.

A falta de referência ética provoca um hedonismo desenfreado e cria a cultura do prazer. O eclipse da ética dos fundamentos eternos faz despontar a aurora da ética do instante, com a conseqüente acentuação das situações vividas, válidas por elas mesmas, sem referência ao transcendente ou apelo à verdade, sem nenhuma projeção para um amanhã previsível ${ }^{24}$. $\mathrm{O}$

\footnotetext{
${ }^{18}$ Cf. V. POSSENTI, Terza navigazione: Nichilismo e metafisica, Roma: Armando, 1998, p. 24 .

19 VOLPI, $O$ niilismo, p. 142.

${ }^{20}$ M. MAFFESOLI, $O$ instante eterno: O retorno do trágico nas sociedades pós-modernas, São Paulo: Zouk, 2003, p.77.

${ }^{21}$ NIETZSCHE, Vontade de potência, p. 145.

${ }^{22}$ VOLPI, $O$ niilismo, p. 140. Sobre a complexa relação entre teologia e ciência, ver o que diz Libanio. Cf. J. B. LIBANIO, "Teologia e ciência”, REB n. 281 (2011) p. 4-16.

${ }^{23}$ VOLPI, $O$ niilismo, p. 140.

${ }^{24}$ Cf. MAFFESOLI, $O$ instante eterno, p. 26.
} 
sujeito niilista vive o cotidiano, sem preocupar-se com o passado e o futuro. Substitui a macro historia da humanidade por sua micro história. Ele não chega a identificar o eticamente correto, já que desconfia da verdade objetiva e se sente no epicentro de um tornado de interpretações possíveis. A concorrência entre referenciais diversos leva o indivíduo a integrar elementos totalmente contraditórios numa síntese muito singular. Afinal, " $O$ que é é plural. A beleza do mundo é polissêmica e, portanto, ambivalente. É a aceitação de tudo isso que, empiricamente, para além dos diversos dever-ser abstratos, constitui o único deve-ser vivido: a complexidade" ${ }^{25}$. A liberdade não exige comprometimento com ideais duradouros, consiste na possibilidade de fazer o que se quer e o que dá prazer.

A Igreja critica, com razões plausíveis, o niilismo, considerando-o uma consequência da crise do racionalismo. Mostra-se preocupada com o fascínio exercido pelo niilismo, cujo calcanhar de Aquiles se encontra na negação da possibilidade de se alcançar a verdade, o que concentra as sensações e experiências no efêmero e no provisório. A razão, por sua vez, incapaz de conhecer a verdade, não chega ao absoluto, como afirma João Paulo II, na encíclica Fides et Ratio (FR 46-47). Ele insiste na necessidade de uma filosofia de alcance metafísico, única em condições de transcender os dados empíricos e chegar a algo absoluto, definitivo e básico. Apresenta como um dos maiores desafios atuais a passagem do fenômeno ao fundamento. Se se nega o fundamento, ou seja, a metafísica, a própria teologia perde o seu sentido. Nesse caso, o intelectus fidei não consegue expressar o valor universal e transcendente da verdade revelada (FR 83). Bento XVI, por sua vez, reforça a posição de seu predecessor, afirmando a razão forte, uma vez que a razão fraca proposta pelo niilismo se mostra incapaz de oferecer orientações precisas para a conduta humana que, entregue a si mesma, se restringe ao efêmero e passageiro, caindo no relativismo. Se a verdade não existe, o ser humano se torna incapaz da moralidade ${ }^{26}$.

O niilismo, no entanto, mesmo reforçando o relativismo, não postula o abandono de causas nobres, fundamentadas na ética e na espiritualidade. Essas causas permanecem válidas, mas apenas como dimensões de uma existência bem mais ampla e indefinível. São causas, ao mesmo tempo, autênticas e efêmeras. O egoísta pode, em determinado momento, de acordo com sua sensibilidade, tornar-se solidário, sem que essa mudança signifique uma conversão em sentido profundo. É o que Michel Maffesoli chama de coincidentia oppositorum. Em épocas passadas, o libertino se distinguia do homem ético e altruísta, religiosamente convicto. Hoje, valores opostos se encontram num mesmo indivíduo e são vividos em hipo ou

\footnotetext{
${ }^{25}$ Ibid., p. 133.

${ }^{26}$ Cf. BENEDETTO XVI, Luce del mondo: Il Papa, la Chiesa e i segni dei tempi. Una conversazione con Peter Seewald, Vaticano: Libreria Editrice Vatincana, 2010, p. 80.
} 
em hiper. Os exemplos se multiplicam. O gozador libertino não dispensa sua sessão mensal de zen. O esposo fiel e bom pai de família aceita participar de uma orgia sexual para dar livre curso às suas fantasias. A jovem fútil e egocêntrica, preocupada com sua beleza, se dedica a uma obra humanitária que demanda tempo e energia. O hedonista ávido para satisfazer seus desejos assume um trabalhado abnegado numa instituição de caridade $^{27}$. Abandona-se a ética como uma instância crítica e propositiva a partir da qual a pessoa organiza sua vida, dando-lhe uma direção precisa. A busca do bem permanece, mas de maneira fragmentada, ou seja, como uma dimensão dentro de tantas outras. A aceitação de um valor nobre não implica renúncia à multiplicidade de significados que a vida oferece.

\section{Cristianismo e niilismo em Gianni Vattimo}

Vattimo, intérprete das filosofias de Nietzsche e Heidegger, abandona a metafísica como busca de uma explicação total sobre o ser. Ao renunciar, na esteira de Nietzsche e Heidegger, à reconstituição da racionalidade metafísica, o filósofo inaugura o pensiero debole (pensamento enfraquecido), que se opõe ao pensamento forte da modernidade. O filósofo italiano afirma que a passagem do moderno ao pós-moderno se caracteriza por uma mudança que vai "da unidade forte à multiplicidade frágil, do domínio à liberdade, do autoritarismo à democracia" ${ }^{28}$. As estruturas fortes da metafísica cedem lugar às estruturas frágeis do pensamento enfraquecido. O niilismo se configura, assim, como ponto de chegada da modernidade e só resta ao pensamento aceitar o fim da metafísica ${ }^{29}$. O filósofo acentua o aspecto positivo do niilismo, a ser aceito como inevitável e como característica essencial do mundo contemporâneo. A fragmentação, a instabilidade e a pluralidade constituem positivamente o real, o que torna desnecessário resgatar a unidade perdida e as hierarquias fortes, construídas de cima para baixo. Seu niilismo, como o de Nietzsche, é gaio, ou seja, acolhe a finitude humana, com suas alegrias e sofrimentos melhor do que a metafísica. O otimismo de Vattimo o distancia de outras interpretações niilistas possíveis ${ }^{30}$. A proposta do filósofo italiano recebe importantes críticas que não interessam ao escopo desse artigo ${ }^{31}$.

${ }^{27}$ Cf. M. MAFFESOLI, $O$ instante eterno, p. 97.

${ }^{28}$ G. VATTIMO, Tecnica ed esistenza: Una mappa filosofica del Novecento, Milano: Bruno Montadori, 2002, p. 66.

${ }^{29}$ Cf. G. VATTIMO, Credere di credere, Milano: Garzanti, 1999, p. 19.

${ }^{30} \mathrm{Cf}$. VOLPI, $O$ niilismo, p. 122-123.

31 Ver, por exemplo, o diálogo entre René Girard e Gianni Vattimo, no qual os autores estabelecem uma mútua apreciação e crítica. Cf. R. GIRARD; G. VATTIMO, Cristianismo e Relativismo, Aparecida: Santuário, 2010. Para uma crítica mais teológica, ver o que diz Ruiz de la Peña. Cf. J. L. R. DE LA PEÑA, El don de Dios: Antopología teológica especial, Santander: Sal Terrae, 1991, p. 319. 
Surpreende em Vattimo que sua proposta não exclua a religião. Segundo ele, com o fim da modernidade, desaparecem também as razões do ateísmo. A crise da modernidade jogou por terra todas as teorias filosóficas que pretenderam eliminar a religião. $\mathrm{O}$ racionalismo ateu que se manifestava como crença exclusiva na ciência experimental e no desenvolvimento da história rumo a uma plena emancipação do homem perdeu força. Com o advento do niilismo, as razões filosóficas que justificam o ateísmo ou a recusa da religião não fazem mais sentido ${ }^{32}$. Não que haja razões fortes metafísicas - para crer, apenas não há razões para não crer. $\mathrm{O}$ niilismo acabou criando um terreno fértil para que a religião pudesse brotar novamente, com toda sua pujança. Uma vez que perece a pretensão metafísica de explicar Deus, a religião ressurge com novas expressões. A morte de Deus, paradoxalmente, provoca o seu renascimento, porque "o fim da metafísica e a morte do Deus moral liquidam as bases filosóficas do ateís$\mathrm{mo}^{\prime \prime 3}$.

Na visão do filósofo, tanto a morte de Deus em Nietzsche quanto o fim da metafísica em Heidegger não são obstáculos para o cristianismo, mas a possibilidade de reencontrá-lo em sua feição de caritas, numa experiência de fé mais parecida com aquele encontro não com o ser da assertiva metafísica, mas com o ser como evento que se mostra e ao mesmo tempo se esconde, permanecendo sempre mistério. Niilismo e cristianismo não se excluem, ao contrário, o cristianismo é niilismo, o que Vattimo demonstra a partir dos conceitos bíblicos de encarnação e kénosis. ${ }^{34} \mathrm{O}$ Deus de Jesus, pela encarnação, se esvazia de sua própria divindade e onipotência, ele se rebaixa, assumindo esse mundo. A revelação de Deus em Jesus se dá através do enfraquecimento do ser, porque a kénosis dissolve a própria metafísica $^{35}$. A encarnação desconstrói a visão forte de Deus, que deixa de se definir como ipsum esse subsistens. Se a secularização se compreende como enfraquecimento do ser, como se deduz da kénosis de Deus em Jesus, o cristianismo atua como "o elemento operante niilista dentro da metafísica" ${ }^{36}$. O filósofo redescobre o cristianismo a partir da tradição filosófica contemporânea do enfraquecimento do ser. Se Deus se fez homem em Jesus, rebaixando-se e assumindo a condição humana, não se pode mais pensá-lo com as categorias fortes da metafísica. A secularização não exige o abandono da hipótese Deus, porque se revela intrínseca ao próprio

\footnotetext{
${ }^{32}$ Cf. VATTIMO, Credere di credere, p. 18.

33 VATTIMO, Depois da cristandade, p. 27.

${ }^{34}$ A articulação entre niilismo e cristianismo em Gianni Vattimo foi apresentada de modo muito consistente na dissertação de Vicente de Paula Ferreira. A participação na banca examinadora dessa dissertação inspirou esse artigo. Cf. V. P. FERREIRA, Niilismo $e$ Cristianismo em Gianni Vattimo, Juiz de Fora: UFMG, 2011.

${ }^{35}$ Cf. VATTIMO, Depois da cristandade, p. 101.

${ }^{36}$ F. P. PIRES, A vocação niilista da hermenêutica: Gianni Vattimo e Religião, São Bernardo do Campo: Universidade Metodista: 2007, p. 185.
} 
cristianismo, uma vez que o eterno secularizou-se em Jesus. O filósofo pensa a secularização a partir dos conceitos de encarnação e de kénosis, mas sua leitura desses temas bíblicos se situa para além de uma interpretação teológico-eclesiástica. "A secularização não é um termo que se choque com a essência da mensagem e sim um aspecto constitutivo: como evento salvífico e hermenêutico, a encarnação de Jesus é ela mesma, acima de tudo, um fato arquetípico de secularização" ${ }^{37}$.

Vattimo sugere que o cristianismo pós-moderno não se baseie em idéias fortes sobre Deus, fundamentadas na metafísica, mas na sua vertente prático-vivencial. O filósofo propõe um cristianismo amigável (amichevole), mais centrado na caridade e menos na moral, no dogma e na disciplina. Um cristianismo que assuma o diálogo, respeitando sua vocação à laicidade, o que o tornaria capaz de respeitar a multireferencialidade conflituosa característica da pós-modernidade. Assim, o cristianismo passaria do universalismo à hospitalidade ${ }^{38}$. Vattimo compreende a caridade como movimento relacional capaz de acolher a diferença na idade da interpretação. "Usando uma linguagem mais explicitamente espiritual, poderíamos dizer que o único limite para a secularização é o amor, a possibilidade de comunicação com uma comunidade de intérpretes" ${ }^{39}$. Sua visão positiva da secularização estabelece a caridade como critério decisivo para o agir humano, porque o próprio Jesus fez da caridade a dimensão crucial da experiência religiosa cristã. Só a caridade desfaz a sabedoria do mundo e o sonho metafísico da religião, que pensa Deus como absoluto, onipotente e transcendente. A partir da kénosis, Deus não se enquadra mais na definição ipsum esse (metaphysicum) subsistens ${ }^{40}$. $\mathrm{O}$ cristianismo reencontrado a partir do abandono da metafísica se enraíza na caridade, mas não coincide exatamente com aquele proposto pela Igreja, cujo aspecto mais crítico, para o filósofo, se encontra na sua vertente dogmática e disciplinar ${ }^{41}$. $\mathrm{O}$ filósofo afirma ter abandonado a fé cristã católica por causa da sua rígida moral sexual, fundamentada no conceito metafísico de moral natural ${ }^{42}$. Por outro lado, mantém sua admiração pela história da santidade cristã, com seus mártires, virgens e confessores ${ }^{43}$. Mesmo reconhecendo aspectos positivos de sua formação católica, que lhe deu consciência política, lamenta que ela tenha sido mais moral e política e menos mística ${ }^{44}$.

${ }^{37}$ VATTIMO, Depois da cristandade, p. 86.

${ }^{38}$ Cf. ibid., p. 126.

${ }^{39}$ Ibid., p. 87.

${ }^{40}$ Cf. VATTIMO, Credere di credere, p. 44.

${ }^{41}$ Cf. ibid., p. 58.

${ }^{42}$ Cf. ibid., p. 70.

${ }^{43}$ Cf. ibid., p. 82.

${ }^{44}$ Cf. ibid., p. 70. 


\section{Niilismo e experiência cristã}

Vattimo representa uma corrente hermenêutica do cristianismo europeu que busca dissociá-lo da metafísica clássica para torná-lo mais aberto, dinâmico e flexível ${ }^{45}$. A mística, que Vattimo diz admirar, não seria um caminho para um cristianismo mais aberto e dinâmico? O filósofo rejeita o dogmatismo, o moralismo e a forte disciplina do cristianismo institucional. Paradoxalmente, tal crítica encontra eco em teólogos contemporâneos. Clodovis Boff, por exemplo, denuncia o déficit espiritual por parte da Igreja, que, às vezes, parece se ocupar mais de problemas burocráticos e administrativos, assumindo um discurso de cunho doutrinário, moralista e disciplinador. Segundo o teólogo, a preocupação mística ou espiritual não é o forte da instituição ${ }^{46}$. Hoje se assiste a um renovado interesse pela mística. A lógica do testemunho parece mais convincente. $\mathrm{O}$ mistério inefável que se anuncia com a vida se revela mais consistente do que qualquer explicação ${ }^{47}$. Se se define a dimensão prático-existencial do cristianismo como a mais importante, talvez os místicos possam se tornar contemporâneos daqueles que escutaram dos lábios de Nietzsche o anúncio da morte de Deus. Mas o que aportaria a experiência mística ao homem pós-moderno, acostumado com o silêncio de Deus e refém do niilismo? O que teriam a dizer os místicos a uma cultura da ausência de Deus? ${ }^{48}$ Seria possível imaginar um itinerarium mentis in Deus per nihilum?

A variada tipologia mística torna difícil sua conceitualização ${ }^{49}$. Em todo caso, partindo dos relatos dos próprios místicos, se define a mística como "uma experiência religiosa particular de unidade-comunhão-presença, onde aquilo que 'se sabe' é precisamente a realidade, o dado desta unidadecomunhão-presença e não reflexão, conceitualização, racionalização do dado religioso vivido" 50 . É um saber não sabendo, como afirmaram alguns místicos. Um saber para além do conceito ou que não cabe num conceito

${ }^{45}$ Cf. F. WILFRED, "Da missão mundial aos cristianismos globais. Uma perspectiva a partir do Sul”, Concilium (Br) n. 339, p. 11-26, 2011, p. 11 aqui.

${ }^{46}$ Cf. C. BOFF, "Perspectivas da experiência religiosa para o novo milênio", in: M. F. DOS ANJOS (Org.). Sob o Fogo do Espírito, São Paulo: Paulinas, 1998, pp. 303-344, aqui pp. 321-322.

${ }^{47}$ Cf. P. A. ARAÚJO, "Mística e cristianismo no início do Novo Milênio. Algumas notas apressadas", Rhema, 35 (2004) pp.75-82, aqui p. 76.

${ }^{48}$ Cf. J. M. VELASCO, El fenômeno místico: Estudo comparado, Madri: Trotta, 1999, p. 487.

${ }^{49}$ Segundo Giovanni Moioli, há três tipos de mística: da essência, esponsal e da ausência. Cf. G. MOIOLI, L'esperienza spirituale: Lezioni introdutive, Milano: Glossa, pp. 82-95. Henrique de Lima Vaz, de um ponto de vista mais filosófico, apresenta também três tipologias místicas: especulativa, mistérica e profética. Cf. VAZ, Experiência mística, pp. 34-93.

50 G. MOILI, "Mística Cristã", in S. de FIORES; T. GOFFI (Org.). Dicionário de Espiritualidade, São Paulo: Paulus, 1993, pp. 769-780, aqui p. 770. 
racional preciso. Trata-se, pois, de um conhecimento incomunicável, cuja característica principal se encontra na inefabilidade. Rahner considera a experiência o dado místico mais importante da própria existência cristã. “O cristão de amanhã ou será um místico, alguém que experimentou alguma coisa, ou deixará de ser cristão" ${ }^{\prime 2}$. Os místicos não negam o discurso metafísico sobre Deus, mas sua palavra sobre Deus se centra na unidadecomunhão-presença e não no conceito, insuficiente para traduzir a incompreensibilidade do mistério. Sem abandonar o dogma, a moral e a disciplina, seu encontro com Deus se realiza na dimensão prático-existencial. Um encontro que é a refundição do próprio ser em Deus. Falam de Deus mais de modo narrativo que discursivo, como Jesus, aliás, que, nas parábolas, mostrou como Deus age na história. Como se dissesse: Deus acontece no mundo quando o amor supera o ódio através do perdão, quando a solidariedade ilimitada faz descobrir o outro como próximo, quando a fraternidade destrói o muro de separação entre ricos e pobres, homens e mulheres, escravos e livres.

Considera-se, às vezes, a mística ilógica, até irracional. Mas a irracionalidade mística não se revela mais razoável do que discursos racionais que dão a impressão de domesticar Deus? Ela inaugura uma nova linguagem para falar de Deus. Claro que o domínio da mística não é o do alógico ou irracional. Ela pertence ao trans-lógico, no qual se apreende uma realidade para além do lógico e do pensamento conceitual ${ }^{52}$. Exatamente essa dimensão trans-lógica a torna tão atraente num contexto marcado pelo niilismo. A mística, do ponto de vista do discurso, apresenta-se como pensamento enfraquecido. Sua linguagem, mais poética e menos conceitual, quer comunicar o inefável e transmitir mais o sabor de Deus do que o saber sobre Deus. Na mística esponsal, a experiência de Deus se realiza de modo gratificante e saboroso, embora possa incluir momentos de prova. É o caso de Santa Teresa de Ávila, por exemplo, cuja mística permanece um paradigma insuperável. O relato de sua experiência de Deus, no Livro da Vida, atrai leitores de diversas áreas do saber. $\mathrm{O}$ excesso do sensível na sua narrativa fala ao homem de hoje, mais atento ao estético do que à razão. Teresa testemunha uma experiência sensibilíssima de Deus e nem por isso superficial, ao contrário, profunda e consistente.

No entanto, a tipologia mística que mais fala ao cristão pós-moderno é a que se define como mística da ausência. Mesmo admitindo a transcendência, do ponto de vista existencial, os místicos da ausência se defrontaram com o nada no seu caminho rumo a Deus. Heidegger afirmara: "conhece muito pouco nossa época quem não experimentou a força do Nada e não foi

${ }^{51}$ RAHNER, "Pietà in passato e oggi", in: Nuovi Saggi II, Roma: Paoline, p. 24.

${ }^{52}$ Cf. VAZ, Experiência mística, pp. 34-35. 
tentado por ela"53. Santa Teresinha, tentada pela força do nada, traço marcante da filosofia do final do século XIX, desabafa:

Parece-me que as trevas, apropriando-se da voz dos pecadores, me dizem, burlando de mim: Sonhas com a luz, com uma pátria aromatizada com os mais suaves perfumes? Sonhas com a posse eterna do Criador de todas essas maravilhas? Crês poder sair um dia das brumas que te rodeiam? Adiante! Aproveite a morte, que te dará não o que esperas, mas uma noite mais profunda ainda, a noite do nada ${ }^{54}$.

Por fim, exclama: “Quando eu canto a alegria do céu, a eterna posse de Deus, não sinto nisso nenhuma alegria, eu canto simplesmente o que eu quero crer $^{55 "}$. Abalada em suas certezas, em crise de fé, propõe a pequena via do amor, a ser percorrida com confiança ilimitada em Jesus na banalidade do cotidiano. Ela é cristã, católica, acolhe o que diz a Igreja, mas sua pequena via é prático-existencial. Mutatis mutandis, sua proposta faz pensar no cristianismo amigável de Vattimo: enfraquecido, destituído da idéia de substância e de essência, sustentado pela confiança inabalável na misericórdia de Deus. Santa Teresinha, sentindo o vestígio do nada, solidária com os que padecem a ausência de Deus, no meio das mais densas trevas, ousa se entregar ao amor na simplicidade do quotidiano. Não busca uma resposta metafísica que a console. Seu caminho se faz na nudez, na dúvida e na desolação. Transforma seu deserto, no qual sente a vertigem do nada, em um oásis às avessas. E, em última instância, encontra Deus no amor abnegado e desinteressado, sem gratificações afetivas, certezas anestesiantes ou compensações humanas. Seu caminho é o da nudez total. Experiência semelhante viveu a beata Teresa de Calcutá.

A escuridão é tal, que realmente não vejo nada - nem com a mente nem com a razão. O lugar de Deus na minha alma é um espaço vazio. Não há Deus em mim. Quando a dor da ânsia é tão grande, só anseio e anseio por Deus, e é então que sinto que Ele não me quer, que Ele não está ali ${ }^{56}$.

Teresa de Calcutá sente a presença de Deus no padecimento de sua ausência. Apenas anseia por Deus. "Tenho apenas a alegria de nada ter, nem sequer a realidade da presença de Deus. Nem oração, nem amor, nem fé, nada a não ser a dor contínua de ansiar por Deus" ${ }^{\prime 2}$. A ausência de Deus se mostra o traço fundamental dessa experiência. E há casos ainda mais

\footnotetext{
${ }^{53}$ E. JÜNGER ; M. HEIDEGGER, Oltre la linea, Milano: Adelphi, 1989, p. 104. Apud F. VOLPI, $O$ niilismo, p. 86.

${ }^{54}$ THERÈSE DE LISIEUX, Histoire d'une âme, Paris: Sarment, 2001, p. 217.

${ }^{55}$ Ibid., p. 218.

${ }^{56}$ B. KOLODIEJCHUK, Madre Teresa: Venha, seja minha luz, Rio de Janeiro: Thomas Nelson, 2008, p. 217. O texto citado foi tirado das cartas que o autor do livro analisa.

${ }^{57}$ Ibid., p. 234.
} 
desconcertantes ${ }^{58}$. A presença de Deus é sentida como ausência sofrida. Dá-se uma forte percepção do sentido do nada. Apesar disso, a pessoa se sente envolvida por uma presença misteriosa e insondável, à qual ela está referida, desde o mais profundo do seu ser.

A mística cristã faz despontar para o niilista um caminho possível rumo ao mistério último, que, em Jesus Cristo, aproximou-se da humanidade, de forma amorosa e gratuita. Trata-se de um mistério que jamais será totalmente sentido, possuído e dominado. O itinerário rumo a Deus, nesse caso, faz do niilismo um momento imprescindível da autêntica experiência do mistério. Ele se torna um itinerarium mentis in Deum per nihilum. Só encontra o rosto de Deus quem atravessa o deserto do nada, do nada das idéias, dos sentimentos, do nada de Deus, daquele Deus construído com limitadas palavras humanas ${ }^{59}$. No vazio de idéias sobre Deus, redescobrese o Deus verdadeiro como o sentido último da própria existência.

A experiência mística, ainda que sofrida, provoca conversão e gera, inclusive, novas energias para a vida moral. Supera-se, assim, paradoxalmente, o relativismo ético que tanto se combate, mas não de maneira teórica, a partir de um discurso metafísico, mas de modo fraco, prático-existencial. A mística potencia a vida moral, porque, em última instância, a conversio moris brota da conversio cordis ${ }^{60}$. As exigências morais da existência cristã passam pela conversão do coração, sem a qual serão sempre sentidas como um fardo pesado imposto pela autoridade ${ }^{61}$. Mas a conversio cordis supõe experiência do mistério. Nesse sentido, todo cristão é chamado a ser místico, alguém que experimenta o mistério de Deus, como afirmara Rahner. Nem todo cristão é chamado a ser místico em sentido estrito ${ }^{62}$, mas o

${ }^{58}$ Cf. MOIOLI, L'esperienza spirituale, p. 92-94. O discernimento desses casos é complexo. A ausência sentida por alguns místicos pode ser provisória, apenas uma etapa de um processo espiritual, mas, em alguns casos, dura a vida toda. Os espirituais recorrem, normalmente, a São João da Cruz, que elabora, magnificamente, o conceito de noite escura. Federico Ruiz, especialista em João da Cruz, faz uma leitura teológica muito profunda e consistente sobre a temática. Cf. F. RUIZ, Místico e mestre São João da Cruz, Petrópolis: Vozes, 1995, p. 256-289.

${ }^{59} \mathrm{Cf}$. VELASCO, El fenômeno místico, p. 481. Os místicos atestam que Deus se situa para além de nomes, palavras, definições e é sempre inefável, por isso, em muitas ocasiões, alguns se tornaram suspeitos de niilismo. Cf. C. D. MORANO, Experiencia mística $y$ psicoanálisis, Santander: Sal Terrae, 1999, p. 27.

${ }^{60}$ Cf. ibid., p. 461.

${ }^{61}$ As observações de González Faus sobre as consequências da falta da mística para a moral sexual da Igreja são muito pertinentes. Cf. J. I. GONZÁLES FAUS, Sexo, verdades e discurso eclesiástico, São Paulo: Loyola, 1999, p. 53-66.

${ }^{62}$ Ruiz, num estudo minucioso sobre mística, diferencia experiência cristã e experiência cristã mística. Segundo o autor, a maioria dos cristãos não faz uma experiência mística de Deus, que permanece uma possibilidade. Por outro lado, há um elemento místico na experiência cristã que precisa ser sempre resgatado, como afirmou Rahner. Cf. F. RUIZ, Le vie dello Spirito: Sintesi di teologia spirituale, Bologna: EDB, 1999, p. 359-360. 
elemento místico da existência cristã se torna indispensável para uma redescoberta de Deus em tempos de niilismo. Sem o fenômeno místico, ou seja, a dimensão experiencial da fé, não se chega ao fundamento. Mas a experiência exige, às vezes, o atravessamento do nada como condição para o verdadeiro encontro com o mistério inefável de Deus.

\section{Conclusão}

Assiste-se hoje, no âmbito dos organismos eclesiais, uma inflação de textos. Há uma propensão a criar leis para tudo e a falar sobre diversos assuntos para cada vez menos pessoas, o que sinaliza incapacidade de se concentrar no essencial. A pressão pós-moderna sobre o catolicismo provoca o reforço das estruturas discursivas e doutrinais ${ }^{63}$. Todos os problemas da Igreja estão resolvidos em documentos e decretos. O reforço doutrinal não consegue esconder, no entanto, uma espécie de aridez espiritual que parece ter se apoderado da interioridade da experiência de Deus. E quando a fé se reduz a um esqueleto conceitual, deixa a impressão de ser apenas mera construção ideológica que não chega a irradiar o mistério e o sabor da transcendência. Num tempo de niilismo e de desconfiança dos discursos racionais, a mística, com sua linguagem poética e até subversiva, ajuda a sair do verbalismo vazio e estereotipado ${ }^{64}$. Ela tem potencial para devolver à palavra da fé seu respiro original e sua linfa mais expressiva. Também é capaz de tirar do evangelho energias novas com as quais falar ao coração do homem.

Ninguém nega a necessidade do fundamento, sem o qual o conceito de verdade se esvazia. Mas, por outro lado, não haveria também a necessidade de uma passagem do fundamento ao fenômeno? Ao fenômeno místico, ou seja, à graça in factu esse. Santo Tomás de Aquino afirmara: actus enim credentis non terminatur ad enuntiabile, sed ad rem (o ato de quem crê não se conclui com o enunciado, mas chega à realidade $)^{65}$. Passar do fun-

\footnotetext{
${ }^{63}$ Cf. C. THEOLBALD, Le christianisme comme style: Une manière de faire de la théologie en postmodernité, Paris: Cerf, 2008, p. 435.

${ }^{64}$ Infelizmente, hoje há discurso que banaliza o mistério de Deus. Trata-se de um discurso repetitivo, mimético e estereotipado. Afirmações absolutas e teologicamente duvidosas são repetidas ad nauseam. Roland Barthes, famoso linguista francês, faz uma afirmação sobre estereótipo que se adequa bem a muitos discursos hodiernos sobre Deus: "o estereótipo é a palavra repetida, fora de toda magia, de todo entusiasmo, como se fosse natural, como se por milagre essa palavra que retorna fosse cada vez adequada por razões diferentes, como se imitar pudesse deixar de ser sentido como uma imitação: palavra sem cerimônia, que pretende a consistência e ignora a sua própria insistência”. Cf. R. BARTHES, $O$ prazer do texto, São Paulo: Perspectiva, 2004, p. 52.

${ }_{65}$ TOMÁS DE AQUINO, Sth II-II q. 1, a. 2, ad 2.
} 
damento ao fenômeno significa passar do enunciado à realidade da experiência de Deus, que o excede enormemente, como atestam tanto místicos quanto niilistas. Levando em consideração o aspecto positivo da crítica de Vattimo, talvez o niilismo pós-moderno esteja exigindo um cristianismo menos apologético e mais epifânico, menos racionalista e mais mistagógico. Um cristianismo mais místico, que mostre mais e demonstre menos.

Paulo Sérgio Carrara CSsR licenciou-se em filosofia (1990) pela Universidade Federal de Juiz de Fora. Fez bacharelado em teologia (1996) na Faculdade Jesuíta de Filosofia e Teologia de Belo Horizonte (FAJE). Mestrado em teologia (2003) com especialização em Espiritualidade na Pontifícia Faculdade Teresianum de Roma. Doutorado em teologia (2010) na FAJE. Atualmente é professor de teologia no Instituto Santo Tomás de Aquino (ISTA) em Belo Horizonte.

Endereço: Rua Tupis, 164 (Centro) 30190-060 Belo Horizonte - MG e-mail:pecarrara@terra.com.br 